\title{
The word part technique: A very useful vocabulary teaching technique
}

Wei Zheng and Paul Nation

\section{Summary}

A very effective way of remembering new vocabulary is to relate it to words that are already known and that contain the same word stem. This article describes the word part technique and how to use it, and provides lists of the most useful stems.

\section{Bio-data}

Wei Zheng teaches at Beijing Foreign Studies University. The ideas in this article come from her PhD research at Victoria University of Wellington, New Zealand. She has taught intensive reading to Chinese English majors for more than ten years. She is interested in second language vocabulary teaching and learning.

weizheng7322@hotmail.com

Paul Nation is emeritus professor of Applied Linguistics in the School of Linguistics and Applied Language Studies at Victoria University of Wellington, New Zealand. He has taught in Indonesia, Thailand, the United States, Finland, and Japan. His specialist interests are language teaching methodology and vocabulary learning. The second edition of his book Learning Vocabulary in Another Language will appear in 2012 from Cambridge University Press.

Paul.Nation@vuw.ac.nz 
There is a very useful vocabulary teaching technique which has been known about for a long time but which is not used often enough. This is the word part technique. Very simply, the word part technique involves connecting a new word to be learned with an already known word which contains the same word part. So, if the teacher wants to help the learners learn the word wary, the teacher needs to point out to them that they already know the word aware which contains the same word part -war-which has the same meaning in both words, namely "to watch something carefully". Here is another example. The high frequency word describe shares the same stem -scrib(e)- with the lower frequency words scribble, subscribe, prescribe, scribe, transcribe, inscribe, etc. These words are similar in form as they all have the word part-scrib(e)- in them. Moreover, they are closely related in meaning because the meaning constant "write" can be found in all of them:

$\begin{array}{ll}\text { describe } & \text { to write about the features of something } \\ \text { scribble } & \text { to write hastily or carelessly } \\ \text { subscribe } & \text { to write down one's name as a buyer of shares or a magazine } \\ \text { prescribe } & \text { to write advice for the use of a medicine } \\ \text { scribe } & \text { somebody in the past who made copies of pieces of writing } \\ \text { transcribe } & \text { to put speech into written form } \\ \text { inscribe } & \text { to write words and symbols on something }\end{array}$

\section{The benefits of using the word part technique}

There are many very good reasons why teachers should use this technique.

1 Almost $60 \%$ of English vocabulary comes from French, Latin, or Greek. These languages make use of word parts - prefixes, suffixes and word stems. So, there is a very large number of words that the word part technique can be used with. In this article we are only going to look at word stems, but recent research has shown that there are at least 2000 word families which belong largely to the mid-frequency words of English (from the $3^{\text {rd }} 1000$ to the $10^{\text {th }} 1000$ ) which have useful word stem connections with the high frequency words from the most frequent 2000 words of English. The word part technique can therefore be used very often.

2 The word part technique is very effective for learning. In many ways this technique is like the keyword technique which uses a linking word to help connect the form of an unknown word with its meaning. In the word part technique, the linking word which acts as the keyword is a word stem from an already known word. It works well.

3 It is easy to learn how to use the word part technique. Most learners and teachers already use it occasionally because it is not generally difficult to see the connection between an unfamiliar word and a known word. But teachers and learners often miss using the technique when it could be used. One of the major purposes of this article is to provide a list of the most frequent word stems which occur in the high frequency words of English and which also occur in many words up to the 10th 1000. This list 
can be used as a way of making sure that learners become familiar with the most useful word stems.

4 The word part technique is more than just a technique to help improve memory for words. It provides useful insights into the English language and its word building system. It also provides an interesting way of understanding some of the history of the English language. This understanding can help language learning, and it is also worth studying in its own right.

5 In this article the word part technique is described as a teaching procedure. This is because it requires some knowledge and skill to make use of it. Eventually however, learners should be able to turn this technique into a strategy that they can use independently. Later in this article, we will look how this can be done.

There are clearly many advantages in using the word part technique, but the use of this technique requires some knowledge of how to use it well. Let us look at that now.

\section{The knowledge needed to use the word part technique}

Teachers and learners need to know which stems are most worth learning so that they get the best return for their teaching and learning effort. There are thousands of word stems in English but not all of them are useful. The most useful word stems are those that occur in many words, are easy to recognise both when they are seen and heard in a word, and have a meaning that remains much the same in the many different words in which they occur. The word stems listed in this article (see Table 1and Table 2) meet all of these criteria. They are part of a much bigger list which is the result of a recent research project (Wei, 2011).

The second piece of knowledge needed is to be able to see the form and meaning connection between a mid-frequency unknown word and a high frequency known word. In Table 1, the high-frequency word containing the word stem is mentioned in the left-hand column. After a bit of practice, it becomes quite easy to see these connections, and some of them are very surprising (and useful). Did you know that the word astonish shares the same stem as the high-frequency word stone? When someone is astonished, it is as if they are turned into stone. The most useful stems given in Table 1 are not as surprising as that. Occasionally, seeing the connection requires a bit of detective work which involves looking up a good dictionary and getting information from the etymology section of the dictionary entries for those words. Ideally, learners' dictionaries would include this information in a very easy accessible form, and one of the goals of the research which led to this article is to encourage dictionary makers to include at least 1000 and up to 2000 word stem hints like those shown in column 1 in Table 1.

Seeing the connection is important. Explaining the connection is even more important and this is where the teacher needs to develop skill in using the technique. Column 1 in Table 1 shows how this explanation can be done. Note in column 1 of Table 1 how the meaning of the stem is included in the sentence that explains the connection between the unfamiliar word and the known word. So, in Table 1 for the stem -vis- which means "see", the word see is 
included in the sentence "Something visible can be seen. Also notice that the word stem is connected to a high-frequency word that the learners already know, in the -vis-example, visit. Making the connection between the word to be learned and the known word is an essential part of the word part technique.

So, to use the word part technique, a teacher needs to be able to check if a word stem is a really useful one or not. Table 1 and Table 2 will help do this, because every stem in those tables is a useful stem. When teachers get good at using the technique, they can check stems by seeing how many other words they can think of which use the same stem. If they can think of at least three or four words, then that is a useful stem to give attention to. The teacher also needs to develop the skill of recognising familiar stems in words that the learners need to learn. This develops with practice. The hardest part of the technique is explaining the connection between the known word and the unknown word. This is why an explanation is provided for every one of the 25 most useful stems in Table 1 . This is easily enough to provide plenty of practice so that the teacher can develop this useful skill for other stems.

\section{Using the word part technique}

The word part technique can be used in two ways. It can be used for the systematic teaching of new words and word stems as a part of a vocabulary lesson. This is probably the most useful way at the beginning to get the learners familiar with the technique. Such a lesson could also be usefully accompanied by a brief description of the history of the English language, explaining how Latin and French had such a strong influence on English vocabulary. The goal of such explanation would be to get the learners interested in the origins of words and the nature of word parts. This lesson can become even more interesting if connections are made with the learners' first language. Teachers can look at where words in the first language came from in the past, and also note the borrowing that is occurring from English into the first language at the present time. In such lessons, it is best to begin by giving attention to the most regular, easily recognised word stems. Then, it is useful to work systematically through the most frequent word stems (those in Table 1) making sure that over a year or so most of these have been covered. Most of these stems occur in at least 10 different word families. Note that the form of some stems can change, for example, -nam-, nom-, -nym-, but their meaning remains much the same.

The other way in which the technique can be used is for dealing with words as they occur as a part of other lessons. For example, when explaining an unfamiliar word during intensive reading, the teacher can use the word part technique to make the explanation stick in the learners' memory.

Repetition and recall are very important learning conditions. If a teacher has spent time drawing attention to a word stem and the words containing it, it is important that the same word stem and the same words are given attention again so that the repetition helps them become well-established in the learners' memory. When the chance to give attention again occurs, it is important that the teacher provides an opportunity for the learners to recall what they have already learnt about the stem and the words containing it. If the learners are unable 
to do this, then the teacher can provide this information again, but it is important that the learners have a chance to recall before the teacher provides such an explanation.

It is possible to make written vocabulary activities such as matching activities or fill the blank activities which practice the word part technique. These may be useful, but it is much more useful if the teacher just uses this technique and thus provides a model for the learners on how they could use the technique.

\section{The word part technique as a learner strategy}

For the learners to use the word part technique as a vocabulary learning strategy, they need to already be familiar with the technique through having experienced it being used by the teacher. When the teacher feels that the learners are ready to use the technique themselves, the teacher can involve them in recognising a word stem in an unfamiliar word, in thinking of an already known word that contains the same stem, and in explaining the meaning of the stem and the connection between the known word and the unfamiliar word. If the teacher does this gradually for at least 20 or 30 different words over several weeks, the learners can then take over control of the technique for themselves so that they can use it independently. This strategy will usually involve the learners looking up words in a dictionary to check the meaning of the stem.

It is important to note that the word part technique is not a way of guessing unknown words from context. It is by far the best if learners guess the meaning of a word from context or look it up in the dictionary to find its meaning, and then apply the word part technique to help the word stick in their memory. The word part technique is not a strategy for finding out the meanings of words, it is a strategy for remembering the meanings of words. It works by relating what is already known to what needs to be learned.

\section{The most useful word stems}

A word stem is useful if it occurs in several different words with the same form and the same meaning. The most useful word stems are listed in order of importance in Table 1.

Table 1: The 25 most useful word stems, their meanings and words containing them

\begin{tabular}{|c|c|}
\hline $\begin{array}{l}\text { The word stem, its meaning, a high frequency word } \\
\text { containing it, and an example of its connection to an } \\
\text { unfamiliar word }\end{array}$ & $\begin{array}{l}\text { Mid-frequency words containing the } \\
\text { word stem }\end{array}$ \\
\hline $\begin{array}{l}\text { - spec(t)-, -spic-, -scope- = "look" as in respect "to look } \\
\text { upon sb with admiration". } \\
\text { A perspective is a particular way of looking at things. }\end{array}$ & $\begin{array}{l}\text { aspect, inspect, prospect, suspect, } \\
\text { spectacle, speculate, perspective, } \\
\text { spectrum, respective, spectacular, } \\
\text { retrospect, spectator, inspectorate, specter, } \\
\text { specify, specimen, despicable, } \\
\text { conspicuous, microscope, kaleidoscope, } \\
\text { telescope, stethoscope, sceptic*, spy* }\end{array}$ \\
\hline $\begin{array}{l}\text {-posit-, -pos- = "put" as in position "a place where sb or } \\
\text { sth is put". } \\
\text { To pose is to put sb into a particular position to be } \\
\text { photographed. }\end{array}$ & $\begin{array}{l}\text { impose, opposite, pose, dispose, compose, } \\
\text { deposit, expose, proposition, compost, } \\
\text { posture, disposition, provost, superimpose, } \\
\text { depose, repository, predispose, } \\
\text { decompose, transpose, compound }\end{array}$ \\
\hline
\end{tabular}




\begin{tabular}{|c|c|}
\hline $\begin{array}{l}\text {-vers-, -vert- = "turn" as in reverse "turn sth the other way } \\
\text { around". } \\
\text { Perverse means thoroughly turned to the wrong way. }\end{array}$ & $\begin{array}{l}\text { versus, adverse, diverse, diversify, } \\
\text { diversion, perverse, traverse, convert, } \\
\text { divert, inverse, revert, inadvertent, pervert, } \\
\text { extrovert, vertebra, vertebrate, subvert, } \\
\text { subversive }\end{array}$ \\
\hline $\begin{array}{l}\text {-vent-, -ven- = "come" as in event "the coming of sth". } \\
\text { A convention is a large meeting where people come } \\
\text { together to discuss some issues. }\end{array}$ & $\begin{array}{l}\text { invent, convention, advent, convent, } \\
\text { circumvent, avenue, convenient, intervene, } \\
\text { revenue, venue, convene, reconvene, } \\
\text { convenor, contravene, souvenir, covenant }\end{array}$ \\
\hline $\begin{array}{l}\text {-ceive-, -cept- = "take" as in accept, receive "to take what } \\
\text { is offered. } \\
\text { To intercept is to take sth when it is on its way from one } \\
\text { place to another. }\end{array}$ & $\begin{array}{l}\text { concept, intercept, deceive, deceptive, } \\
\text { perception, perceive, reception, receipt, } \\
\text { receiver, receptive, misconception, } \\
\text { perceptive, receptor, misconceive, } \\
\text { susceptible }\end{array}$ \\
\hline $\begin{array}{l}\text {-super- = "above" as in super "being above sb or sth". } \\
\text { To be supervised is to be directed by sb above you. }\end{array}$ & $\begin{array}{l}\text { superb, supermarket, supervise, superior, } \\
\text { superintendent, superficial, superman, } \\
\text { supersede, superfluous, superstore, } \\
\text { supernatural, superstar, superstructure, } \\
\text { superpower, supersonic }\end{array}$ \\
\hline $\begin{array}{l}\text {-nam-, -nom-, -nym- = "name" as in name. } \\
\text { To nominate is to put one's name forward for election. }\end{array}$ & $\begin{array}{l}\text { surname, nickname, rename, nominate, } \\
\text { nominal, misnomer, renown, nominee, } \\
\text { denomination, anonymous, synonym, } \\
\text { acronym, anonymity, pseudonym, noun* }\end{array}$ \\
\hline $\begin{array}{l}\text {-sens-, -sent- = "feel, sense" as in sense. } \\
\text { Consent means having the same feelings and opinions } \\
\text { about sth and therefore be in agreement. } \\
\text { Sensual means of the pleasures of the senses. }\end{array}$ & $\begin{array}{l}\text { sentence, sensible, nonsense, sensitive, } \\
\text { sensual, sensor, scent, sensation, } \\
\text { consensus, resent, sentiment, consent, } \\
\text { assent, dissent }\end{array}$ \\
\hline $\begin{array}{l}\text {-sta-, -stan-, -stat- = "stand" as in stand. } \\
\text { Instant means happening quickly without anything } \\
\text { standing in between two events. }\end{array}$ & $\begin{array}{l}\text { stable, stall, status, distant, circumstance, } \\
\text { instant, stance, static, obstacle, stool*, } \\
\text { statue, pedestal, stature }\end{array}$ \\
\hline $\begin{array}{l}\text {-mit-, -mis- = "send" as in committee "a group of people } \\
\text { who are sent to be together to conduct some particular } \\
\text { business". } \\
\text { To transmit is to send out electric signals. }\end{array}$ & $\begin{array}{l}\text { permit, transmit, submit, emit, remit, omit, } \\
\text { message, mission, premise, dismiss, } \\
\text { missile, submission, demise, omission }\end{array}$ \\
\hline $\begin{array}{l}\text {-mid-, -med(i)- = "middle" as in middle. } \\
\text { Mediocre means being in the middle position ranging } \\
\text { from good to bad. }\end{array}$ & $\begin{array}{l}\text { immediate, medium, media, medieval, } \\
\text { intermediate, Mediterranean, mediocre, } \\
\text { mediate, meridian, meddle, median, } \\
\text { intermediary, amid }\end{array}$ \\
\hline $\begin{array}{l}\text {-pris-, -pre- = "take" as in surprise "sth which takes your } \\
\text { attention unexpectedly". } \\
\text { If sth comprises a number of things, it takes them in as its } \\
\text { parts. }\end{array}$ & $\begin{array}{l}\text { prison, enterprise, comprise, apprentice, } \\
\text { prey, apprehend, comprehend, predatory, } \\
\text { entrepreneur, incomprehensible, } \\
\text { apprehension, comprehensive, } \\
\text { entrepreneurial }\end{array}$ \\
\hline $\begin{array}{l}\text {-dict-, -dicate = "say" as in indicate "to say sth indirectly". } \\
\text { To dedicate as book or an artistic word to sb is to say that } \\
\text { a book or an artistic work is issued or performed in one's } \\
\text { honor. }\end{array}$ & $\begin{array}{l}\text { dictate, dedicate, abdicate, predicate, } \\
\text { vindicate, predict, contradict, verdict, } \\
\text { indict, diction, ditto*, index* }\end{array}$ \\
\hline $\begin{array}{l}\text {-cess- = "go" as in process "actions gone through". } \\
\text { Making a concession involves going along with sb's } \\
\text { opinions. }\end{array}$ & $\begin{array}{l}\text { access, excess, recession, concession, } \\
\text { recess, ancestor, predecessor, procession, } \\
\text { succession, abscess, microprocessor, cease }\end{array}$ \\
\hline $\begin{array}{l}\text {-form- = "form" as in form. } \\
\text { The format of a book is its form such as its shape, size }\end{array}$ & $\begin{array}{l}\text { formal, perform, transform, uniform, } \\
\text { format, conform, formula, reform, deform, }\end{array}$ \\
\hline
\end{tabular}




\begin{tabular}{|c|c|}
\hline design. & formative, morphology* \\
\hline $\begin{array}{l}\text {-tract- = "draw" as in attract "to draw attention". } \\
\text { To extract is to draw sth out. }\end{array}$ & $\begin{array}{l}\text { extract, distract, abstract, subtract, detract, } \\
\text { retract, contraction, protracted, traction, } \\
\text { tractor, intractable }\end{array}$ \\
\hline $\begin{array}{l}\text {-graph- = "write" as in paragraph "a written passage". } \\
\text { A telegraph is sending a written messages using radio } \\
\text { signals. }\end{array}$ & $\begin{array}{l}\text { telegraph, autobiography, biography, } \\
\text { pornography, autograph, biographer, } \\
\text { typographical, graph, graphic, topography, } \\
\text { demography, geography }\end{array}$ \\
\hline $\begin{array}{l}\text {-gen- = "produce" as in generate "produce". } \\
\text { Genes are part of a cell that produces similar features in } \\
\text { children. }\end{array}$ & $\begin{array}{l}\text { genuine, gene, genesis, genetic, genius, } \\
\text { indigenous, ingenuity, engender, } \\
\text { congenital, genital, ingenious }\end{array}$ \\
\hline $\begin{array}{l}\text {-duce-, -duct- = "lead" as in introduce/introduction } \\
\text { "leading sth/sb into a place, condition or circle of people". } \\
\text { To induce is to lead sb to do sth unwise. }\end{array}$ & $\begin{array}{l}\text { induce, deduce, seduce, conducive, } \\
\text { conduct, abduct, viaduct, aqueduct, } \\
\text { superconductor, subdue }\end{array}$ \\
\hline $\begin{array}{l}\text {-voca-, -vok- is a variation of -voic- = "voice" as in voice. } \\
\text { To advocate is to voice one's opinions publicly to support } \\
\text { sth. }\end{array}$ & $\begin{array}{l}\text { advocate, vocabulary, vocal, } \\
\text { invoke/invocation, equivocal, } \\
\text { evoke/evocation, vowel, advocacy }\end{array}$ \\
\hline $\begin{array}{l}\text {-cis-, -cid- = "cut" as in decide/decision "a judgment about } \\
\text { where to cut off (what to do or not to do). } \\
\text { To excise is to remove by cutting sth out. }\end{array}$ & $\begin{array}{l}\text { precise, excise, circumcise, concise, incise, } \\
\text { scissors, suicide, pesticide }\end{array}$ \\
\hline $\begin{array}{l}\text {-pla- is a variant of -fla- = "flat" as in flat. } \\
\text { A plaice is a flat sea fish. }\end{array}$ & $\begin{array}{l}\text { plain, plane, plate, plaice, plateau, plot*, } \\
\text { flounder* }\end{array}$ \\
\hline $\begin{array}{l}\text {-sec-, -sequ- = "follow" as in second "following the first". } \\
\text { A consequence is what follows as an effect. }\end{array}$ & $\begin{array}{l}\text { consequence, sequence, subsequent, } \\
\text { consecutive, sequel, prosecute, } \\
\text { consequential }\end{array}$ \\
\hline $\begin{array}{l}\text {-for }(\mathrm{t})-=\text { "strong" as in force. } \\
\text { A fortress is a very strong building for protecting people. }\end{array}$ & $\begin{array}{l}\text { fortress, fortified, fortitude, comfort, } \\
\text { effort, fort, enforce, reinforce, forte }\end{array}$ \\
\hline $\begin{array}{l}\text {-vis- = "see" as in visit "go to see someone". } \\
\text { Something visible can be seen. }\end{array}$ & $\begin{array}{l}\text { visible, envisage, revise, supervise, visual, } \\
\text { vision, television }\end{array}$ \\
\hline
\end{tabular}

Note: The words with the * mark show variations in form.

In the row for $-f o r(t)$ - at the bottom of the table, we can see that the stem takes two forms (for, fort). Its meaning "strong" is given in quotation marks and force is a word from the most frequent 2000 words of English containing the stem. The example mid-frequency word fortress, which happens to be the first of the words given in column 2 of the table, is followed by an explanation or hint that shows how the meaning of -fort- is related to the meaning of fortress. Any of the words in column 2 could have a similar hint to help learning. For example, Fortitude is the strength to continue doing something. Effort is the amount of strength needed to do something. All the words in column 2 are from the $3^{\text {rd }}$ to $10^{\text {th }} 1000$ words of English. The data in column 1 with appropriate changes to the example could be included in a dictionary entry for each of the words in column 2.

To see how well you understand and can use the word part technique, try making the connecting explanation for some of the words in column 2. For example, for the stem -prec-, We appreciate something when we know its high value. Also see if you can find the stems in these words - television, prize, fortitude.

The twenty five stems in Table 1 provide access to about 300 mid-frequency words. 
Table 2: Alphabetically arranged stems that are in at least 5 words (not including the stems listed in Table 1)

\begin{tabular}{|c|c|c|}
\hline $\begin{array}{l}\text {-ag- agent, agitate (act) } \\
\text {-angl- angle, ankle, anchor } \\
\text {-aster-, -astro- disaster (star) } \\
\text {-audi-, audience (listen) } \\
\text {-b-1- ball, bulge, bulk, belly } \\
\text {-b-n-, benefit, bonus, bounty } \\
\text { br- brand, brew, brood (heat) } \\
\text {-car-, carry, cargo, caravan } \\
\text {-cav-, ca- cave, cabinet (hollow) } \\
\text {-ced-, -ceed- proceed (go) } \\
\text {-ceive-, -cept- accept (receive) } \\
\text {-cent- accent (emphasis) } \\
\text {-cess- process, access (go) } \\
\text {-chemist-, -chemical chemical } \\
\text {-cis-, -cid- decide (cut) } \\
\text {-clam-, -claim- claim (say) } \\
\text {-clus-, -clud- include (close) } \\
\text {-corp- corporation (body) } \\
\text {-course-, -co(ur)- course (run) } \\
\text {-cur- secure, accurate (care) } \\
\text {-cur(s)- current, cursor (run) } \\
\text {-dom- control (dominate) } \\
\text {-electr-electricity } \\
\text {-equa-, -equi- equal, equivalent } \\
\text {-fa- fame, infant, fable (speak) } \\
\text {-fer- offer, confer (bring) } \\
\text {-fin- finish, define (limit) } \\
\text {-flo-r- flower, flour, flourish } \\
\text {-flu- influence, fluid (flow) } \\
\text {-gl- glass, glitter (shine) } \\
\text {-gno- know, diagnose (ignore) } \\
\text {-grad- grade, gradual (degree) } \\
\text {-f(-)a(c)- fact, manufacture (do) }\end{array}$ & $\begin{array}{l}\text {-gress- progress, regress (step) } \\
\text {-hibit-, -habit- prohibit (hold) } \\
\text {-hum(an)- human, humble } \\
\text {-ject- reject, objective (throw) } \\
\text {-join-, -junct- join, juncture } \\
\text {-jud-, -jur- judgement, jury } \\
\text {-c-n- can, cunning, keen (know) } \\
\text {-leg- legal, privilege (law) } \\
\text {-like- like, alike, unlike, likeness } \\
\text {-lit- letter, obliterate, literate } \\
\text {-locate, -local- local (place) } \\
\text {-long- long, length, prolong } \\
\text {-ma(g)- magnificent (important) } \\
\text {-ma(j)- major ( important_ } \\
\text {-man-, -main- remain (stay) } \\
\text {-mar-, -mer- market (trade) } \\
\text {-memor- memory (remember) } \\
\text {-meter meter (measure) } \\
\text {-mil(li)- million (thousand) } \\
\text {-min(im)- minimum (small) } \\
\text {-m-n- mind, monument, mental } \\
\text {-neg- neglect, renege, negate (not) } \\
\text {-nerv-, -neuro- nerve } \\
\text {-not- note, notion, annotate (idea) } \\
\text {-nounc- announce (say) } \\
\text {-num- number, enumerate } \\
\text {-par- compare, par, parity, peer } \\
\text {-part- part, partner, particle } \\
\text {-pel- appeal, propel (force) } \\
\text {-pend- depend, pendulum (hang) } \\
\text {-pla-, plea- please, complacent } \\
\text {-plant- plant, transplant, implant } \\
\text {-p-n- pain, penalty, punish }\end{array}$ & $\begin{array}{l}\text {-port- transport, report (carry) } \\
\text {-prec-, -pr-/z/- price, prize (value) } \\
\text {-prim- prime, primary (first) } \\
\text {-publi(c)- public, publish } \\
\text {-puls- pulse, compulsion (push) } \\
\text {-quali- quality, qualify, quasi } \\
\text {-(re)lat- relate, collate, atlas } \\
\text {-sal-, -sau- salt, salad, sauce } \\
\text {-scal-, -scend- scale (climb) } \\
\text {-sec-, -sequ- second (follow) } \\
\text {-sect-, -seg- section, insect } \\
\text {-sed-, -sid- reside (setttle) } \\
\text {-sens-, -sent- sense, sentence } \\
\text {-sent, -senc- sense, resent (feel) } \\
\text {-serv- service, deserve (do) } \\
\text {-sim-, -sem- similar, assemble } \\
\text {-soci(al)- social, socialism } \\
\text {-sound-, -son- sound, consonant } \\
\text {-/s/pir- spirit, expire (breath) } \\
\text {-sti- stick(vb), distinct, stitch } \\
\text {-struct- structure, construct } \\
\text {-syn- system, syndrome, synthesis } \\
\text {-tele- television, telex (far) } \\
\text {-ten- tend, tense, tent (stretch) } \\
\text {-ten-, -tent- contents (hold) } \\
\text {-tent-, -tain- maintain (keep) } \\
\text {-term- term, exterminate (end) } \\
\text {-val(u)- value, valid, equivalent } \\
\text {-vid-, -vis- divide, divisive } \\
\text {-voca-, -vok- voice,invoke } \\
\text {-wr-n-, -wor- worry, wrinkle, } \\
\text { (twist) }\end{array}$ \\
\hline
\end{tabular}

Table 2 contains almost 100 word stems which are the most useful ones after those in Table 1. Each stem occurs in at least five mid-frequency words. The word in italics is a high frequency word containing the stem, and the word in brackets is the meaning of the stem. Where the example and meaning are the same, only one is given, for example-car-carry. Where there is space in the table, extra examples are given, so in the entry for-pla-, plea- the most common word is please and the meaning of the stems is "please", and complacent is a low frequency example.

\section{References}

Wei, Z. (2012). Word roots in English - Learning English words through form and meaning similarity. PhD Thesis, Victoria University of Wellington, New Zealand. 